\title{
A Study on Control of Microorganisms in Drinking Water Using Ag-Cu/C Catalysts
}

\author{
K. Hari Prasad Reddy ${ }^{1}$, V. Shashikala ${ }^{1}$, N. Anand ${ }^{1}$, C. Sandeep ${ }^{2}$, B. David Raju ${ }^{1}$ and \\ K.S. Rama Rao ${ }^{*}, 1$ \\ ${ }^{I}$ Inorganic and Physical Chemistry Division, Indian Institute of Chemical Technology, Uppal Road, Hyderabad - \\ 500607, India \\ ${ }^{2}$ Department of Chemical and Biological Engineering, 310 Ricketts Building, Rensselaer Polytechnic Institute, Troy, \\ New York, 12180, USA
}

\begin{abstract}
Ag}-\mathrm{Cu}$ supported on activated carbon $(\mathrm{Ag}-\mathrm{Cu} / \mathrm{C})$ catalysts with different compositions of $\mathrm{Ag}$ and $\mathrm{Cu}$ (total loading of $\mathrm{Ag}+\mathrm{Cu}=1$ weight \%) were prepared by wet impregnation technique. These catalysts were characterized by BET surface area XRD, TPR, TEM and XPS. The catalytic activity of these catalysts was tested for control of microorganism in drinking water by nutrient agar coating method. Catalyst containing $0.5 \mathrm{~g}$ each of $\mathrm{Ag}$ and $\mathrm{Cu}$ respectively exhibited superior catalytic activity compared to those of remaining compositions. The high catalytic activity possessed by this catalyst is attributed to the presence of smaller $\mathrm{Ag}$ particles and interaction between $\mathrm{Ag}$ and $\mathrm{Cu}$ as evidenced by XRD, TPR, XPS and TEM results respectively.
\end{abstract}

Keywords: $\mathrm{Ag}-\mathrm{Cu} / \mathrm{C}$ catalysts, microorganism control, impregnation technique, water purification.

\section{INTRODUCTION}

Home owners increasingly concern about contaminants in their drinking water supply because of adverse effects on health due to the presence of bacteria and other microorganism. The presence of bacteria is the main indication of water contamination. A World Health Organization (WHO) investigation showed that $80 \%$ of disease is due to contaminated drinking water $[1,2]$. The WHO recommended that any water intended for drinking should contain fecal and total coliform counts of 0 in $100 \mathrm{~mL}$ sample [1]. To achieve this goal, chemical agents and physical treatments, such as ozone, chlorine and its derivatives, ultraviolet light and radiation, are commonly used [3]. However, these agents can easily give rise to unwanted side-effects to human health, as well as to singular events and big dosage shortcomings. The antibacterial effects of metallic silver have been known for centuries [46]. This beneficial property originates from silver ions dissolving from the surface of bulk silver [7]. In contrast to the use of silver ions, the biocidal effect of bulk silver is long lasting and stable. However, it is difficult to apply bulk silver in industrial or domestic applications because of its high price and low ion release rate. Recently, the application of silver nanoparticles has ushered in a new approach to the application of silver antimicrobial agents. Several investigations have been carried out to find out the bactericidal effect of nanoparticles and their applications in the plastics, health, textile, and paint industries [8-12]. In

*Address correspondence to this author at the Inorganic and Physical Chemistry Division, Indian Institute of Chemical Technology, Uppal Road, Hyderabad - 500607, India;

Tel: +91-40-27191712; Fax: +91-40-27160921;

E-mails:ksramarao@iict.res.in, ksramaraoiict@yahoo.com comparison with bulk silver, silver nanoparticles release of silver ions with a controllable rate [13]. Therefore, nanoparticles are expected to play a crucial role in the food industry, water disinfection, and other applications related to disinfection $[14,15]$. In our previous report silver on carbon covered alumina prepared by electrochemical deposition method has shown great potential towards purification of drinking water [16]. The objective of present work is to cut down the cost $\mathrm{Ag} / \mathrm{C}$ catalyst by diluting it with $\mathrm{Cu}$ without compromising the activity towards microorganism control in drinking.

\section{MATERIALS AND METHODOLOGY}

\section{Preparation of Catalysts}

Commercially available activated carbon Support (M/s. Norrit Corporation, USA) has been used for silver-copper catalysts. Silver and copper are supported on activated carbon by impregnation method. $\mathrm{Cu}\left(\mathrm{NO}_{3}\right)_{2} \cdot 3 \mathrm{H}_{2} \mathrm{O}$ and $\mathrm{AgNO}_{3}$ ( M/s. Loba Chemie, India) are the metal precursors used for copper and silver respectively. The catalysts were prepared with varied composition of silver and copper taking increments of one metal and decrements of other metal by $0.25 \%$ by weight. Requisite amount of $\mathrm{Ag}$ and $\mathrm{Cu}$ salts are dissolved in water and the support has been dipped in this solution followed by heating to remove excess water. The resultant mass was dried in the oven for 12 hours. The samples were subjected to calcination in the flow of nitrogen $\left(30 \mathrm{~cm}^{3} \mathrm{~min}^{-1}\right)$ at $673 \mathrm{~K}$ for 4 hours. These catalysts were designated as $1 \mathrm{Ag}-0 \mathrm{Cu} / \mathrm{C}, 0.75 \mathrm{Ag}-0.25 \mathrm{Cu} / \mathrm{C}, 0.5 \mathrm{Ag}-0.5 \mathrm{Cu} /$ $\mathrm{C}, 0.25 \mathrm{Ag}-0.75 \mathrm{Cu} / \mathrm{C}$ and $0 \mathrm{Ag}-1 \mathrm{Cu} / \mathrm{C}$ which corresponds to $1 \% \mathrm{Ag}, 0.75 \% \mathrm{Ag}$ plus $0.25 \% \mathrm{Cu}, 0.5 \% \mathrm{Ag}$ plus $0.5 \% \mathrm{Cu}$, $0.25 \% \mathrm{Ag}$ plus $0.75 \% \mathrm{Cu}$ and $1 \% \mathrm{Cu}$ by weight respectively. The compositions of all these catalysts are listed in Table $\mathbf{1}$. 
Table 1. Physico-Chemical Characteristics of the Catalysts

\begin{tabular}{|c|c|c|c|c|c|c|c|}
\hline \multirow{2}{*}{ S. No. } & \multirow{2}{*}{ Catalyst Code } & \multicolumn{2}{|c|}{ Catalyst Composition, wt $\%$} & \multicolumn{2}{|c|}{ BET Surface Area } & \multicolumn{2}{|c|}{ Crystallite Size, nm } \\
\hline & & Ag & $\mathbf{C u}$ & $\mathrm{m}^{2} \mathrm{~g}^{-1}$ Catalyst & $\mathrm{m}^{2} \mathrm{~g}^{-1}$ Support & Ag & $\mathrm{Cu}$ \\
\hline 1 & Carbon & 0 & 0 & 912 & 912 & - & - \\
\hline 2 & $1 \mathrm{Ag}-0 \mathrm{Cu} / \mathrm{C}$ & 1.0 & 0 & 765 & 773 & 68 & - \\
\hline 3 & $0.75 \mathrm{Ag}-0.25 \mathrm{Cu} / \mathrm{C}$ & 0.75 & 0.25 & 833 & 841 & 47 & - \\
\hline 4 & $0.5 \mathrm{Ag}-0.5 \mathrm{Cu} / \mathrm{C}$ & 0.5 & 0.5 & 775 & 783 & 38 & - \\
\hline 5 & $0.25 \mathrm{Ag}-0.75 \mathrm{Cu} / \mathrm{C}$ & 0.25 & 0.75 & 889 & 898 & 28 & - \\
\hline 6 & $0 \mathrm{Ag}-1 \mathrm{Cu} / \mathrm{C}$ & 0 & 1.0 & 879 & 888 & - & - \\
\hline
\end{tabular}

\section{Characterization of Catalysts}

Characterization of catalysts by BET (Brunauer, Emmett and Teller) surface area, XRD, TEM, XPS and activity studies were carried out after reducing the catalysts in $\mathrm{H}_{2}$ flow at $523 \mathrm{~K}$. Surface areas of the reduced $\mathrm{Ag}-\mathrm{Cu} / \mathrm{C}$ catalysts were measured by the physisorption of nitrogen at $77 \mathrm{~K}$, (BET method) using a Smart Sorb 92/93 equipment (M/S.SMART Instrument, India). For the estimation of BET surface area, $30 \% \mathrm{~N}_{2} /$ helium gas mixture. Prior to measurement, the samples were degassed at $473 \mathrm{~K}$ for $2 \mathrm{~h}$. The XRD patterns of the reduced $\mathrm{Ag}-\mathrm{Cu} / \mathrm{C}$ samples and pure carbon were recorded on a Rigaku Miniflex X-ray diffractometer (M/s. Rigaku Corporation, Japan) using $\mathrm{Ni}$ filtered $\mathrm{Cu} \mathrm{K} \alpha$ radiation in a $2 \theta$ range of $2^{\circ}$ to $80^{\circ}$ and with $2 \theta$ scan speed of $2 \% / \mathrm{min}$.

Crystallites size (L) can be determined from the corrected line broadening $(\beta)$ in the sample using Debye-Scherer equation.

$\mathrm{L}=\mathrm{k} \lambda / \beta \cos \theta$

where, $\theta=$ incident angle

$\lambda=$ Wavelength

$\mathrm{L}=$ thickness of the crystal in a direction perpendicular to the diffracting plane.

$\mathrm{K}=$ constant $(\sim 0.9-1.0)$

Instrumental broadening is determined by using a highly crystalline silicon standard $(\mathrm{d}=3.1345)$. B is the line width on the $2 \theta$ scale in radians, corrected for instrumental broadening as given below.

$\beta=\sqrt{ }\left(\omega_{1}^{2}-\omega_{2}^{2}\right)$

where, $\omega_{1} \& \omega_{2}$ are FWHM of sample \& silicon standard lines respectively in the raw data..

Crystal sizes of the Ag have been calculated for the catalyst samples. However, crystallite size of $\mathrm{Cu}$ could not be calculated because of the poorly crystalline nature of $\mathrm{Cu}$

Temperature programmed reduction (TPR) patterns of calcined samples of activated carbon support and the catalysts were obtained using a home made on-line quartz micro reactor interfaced to a thermal conductivity detector (TCD) equipped gas chromatograph (GC) which in turn was connected to a data station (comprising of a standard GCsoftware supplied by Hindetron, India). For recording the TPR profiles. $\mathrm{H}_{2} / \mathrm{Ar}$ ( 6 vol. $\%$ of $\mathrm{H}_{2}$ and balance Ar) mixture was allowed to flow on to the catalyst bed and simultaneously the catalyst bed was heated at a linear ramp of $5 \mathrm{Kmin}^{-1}$ from 303 to $973 \mathrm{~K}$ and kept at the final temperature isothermally for $30 \mathrm{~min} . \mathrm{H}_{2} / \mathrm{Ar}\left(6\right.$ vol. \% of $\mathrm{H}_{2}$ and balance $\mathrm{Ar}$ ) mixture was also used as a carrier gas to the TCD equipped GC. Whenever there is a change in the concentration of $\mathrm{H}_{2}$ from the mixture gas, due to reduction of either silver oxide or copper oxide or carbon a signal (peak) will be detected the TCD detector and these will be recorded by the GC software The experimental details of the TPR run were discussed elsewhere [17].

Transmission electron micrographs (TEM) of selected catalysts in reduced state were recorded on a Phillips Tecnai $\mathrm{G}^{2}$ FEI F12 electron microscope. The powder samples were dispersed in ethanol by ultrasonication before loading onto a carbon-coated copper grid and then allowed to dry at room temperature before recording the micrographs.

XPS measurements for the selected catalysts in reduced state were performed on a Kratos X-ray photoelectron spectrometer. The X-ray excitation energy was $1253.6 \mathrm{eV}$ $(\operatorname{Mg} K \alpha)$, and the spectra were recorded with pass energy of $80 \mathrm{eV}$.

\section{Activity Test}

Activities of all metal supported catalysts were tested for control microorganism in raw water by using $0.1 \mathrm{~g}$ catalyst. Prior to the activity run, the catalyst was reduced at $523 \mathrm{~K}$ for $3 \mathrm{~h}$ in $\mathrm{H}_{2}$ flow $\left(30 \mathrm{~cm}^{3} \mathrm{~min}^{-1}\right)$. Further $0.1 \mathrm{~g}$ of the catalyst was dipped in $50 \mathrm{~cm}^{3}$ raw water (pond water, which contains plenty of microorganisms with E.coli as main bacterial type present) taken in a $100 \mathrm{ml}$ sterile, transparent vessel with screw cap and stirred for $1 \mathrm{~h}$ in a batch mode at room temperature. After $1 \mathrm{~h}$, the catalyst was filtered off and the water was tested for the presence of bacteria quantitatively.

\section{Quantitative Analysis of Microorganisms}

Water to be tested was serially diluted [18] to $10^{6}$ dilution in a series of six test tubes. One millilitre of the raw water was taken in the first test tube containing $9 \mathrm{ml}$ of saline solution and from it $1 \mathrm{ml}$ was taken into the second test tube also containing $9 \mathrm{ml}$ of saline solution. This process was repeated upto, i.e., $10^{6}$ dilution. Since the raw water contains large number of microorganisms, it is difficult to count the number of organisms present in it. So, it is necessary to dilute it. From each test tube $0.1 \mathrm{ml}$ of water was taken and was spread using a spreader, on a petri-plate containing solidified nutrient agar and were incubated at $310 \mathrm{~K}$ for $24 \mathrm{~h}$ 
[18]. This entire process was done in the UV laminar airflow. The number of colonies grown was then counted after incubation. This process was performed around 16 batches using $0.1 \mathrm{~g}$ catalysts for all $\mathrm{Ag}-\mathrm{Cu}$ catalysts. The quantification of microorganisms in the water was done after vigorous stirring of about $50 \mathrm{ml}$ of raw water with the catalyst taken and after filtering off the catalyst.

\section{Nutrient Agar Preparation}

Twenty-eight grams of nutrient agar was dissolved in $1000 \mathrm{ml}$ of water and was autoclaved at $394 \mathrm{~K}$ and at a pressure of $15 \mathrm{lbs}$ for around $15 \mathrm{~min}$, samples were taken out after reducing the pressure to atmospheric pressure. Then after cooling it was distributed in 36 Petri-plates with $5 \mathrm{ml}$ in each Petri-plate and left for solidification.

\section{Preparation of the Saline Solution (0.96 wt.\%) and Plating}

$2.88 \mathrm{~g}$ of $\mathrm{NaCl}$ was dissolved in $300 \mathrm{ml}$ of distilled water. $9 \mathrm{~cm}^{3}$ of this saline solution was distributed in 30 test tubes. They were covered with a cotton plug and were autoclaved as above. They were then cooled and inoculated [18]. $0.1 \mathrm{ml}$ of the inoculated culture from these test tubes was taken and spread on the agar Petri-plates for quantification of microorganisms. Thus, prepared agar plates were incubated for $24 \mathrm{~h}$ at a temperature of $310 \mathrm{~K}$ [18].

\section{RESULTS AND DISCUSSION}

\section{Catalyst Characterization}

Adsorption studies of $\mathrm{N}_{2}$ gas onto the samples gives information about the change in the surface area of the carbon support due to the deposition $\mathrm{Ag}$ or $\mathrm{Cu}$ or both by impregnation method. Surface area values of the support and $\mathrm{Ag}-\mathrm{Cu}$ supported catalysts are shown in Table 1. Surface area of the support has exhibited the major decrease when Ag particles are deposited on the support. The factors that decide the surface area of the catalyst are pore blockage and the presence of nano particles of $\mathrm{Ag}$ or $\mathrm{Cu}$ or both, in the sample. It is interesting to observe that in $\mathrm{Cu}$ rich catalysts $(0 \mathrm{Ag}-1 \mathrm{Cu} / \mathrm{C}$ and $0.25 \mathrm{Ag}-0.75 \mathrm{Cu} / \mathrm{C})$, the surface area is more or less same as that of pure support. This can be further evidenced from the surface area value per gram support (Surface area of the catalyst divided by total metal content (0.99) in I g catalyst). In other words, the metal content of $0.01 \mathrm{~g}$ is excluded; surface area due to support contribution is resulted. Since this value in the catalysts, $0 \mathrm{Ag}-1 \mathrm{Cu} / \mathrm{C}$ and $0.25 \mathrm{Ag}-0.75 \mathrm{Cu} / \mathrm{C}$ is close to that of pure support, one can say the absence of pore blockage due to $\mathrm{Cu}$. This is a clear indication of absence of pore blockage in carbon by copper particles. This is possible when copper particles of porous structure or very small particles of $\mathrm{Cu}$ are present. From the above data, one can believe that pore blockage by $\mathrm{Ag}$ is more significant than $\mathrm{Cu}$.

Fig. (1) shows the XRD pattern of activated carbon supported silver-copper catalysts. It is evident from the patterns that sliver is in the crystalline state and that copper is in the amorphous form ( 1 ize $<40 \AA$ ). The support activated carbon is also in the amorphous state. The XRD patterns of the samples with $0.50 \mathrm{wt}$ percent to $0.75 \mathrm{wt}$ percent Ag show major $\mathrm{d}$ values for metallic silver phase at 2.36, 2.04, 1.44, 1.24 and $2 \theta$ values at $38.02,44.15,64.32,77.33^{\circ}$ due to $\mathrm{Ag}$
(111), Ag (200), Ag (220) and Ag (311) planes. Respectively (ICSD File No. 064997). The intensity of Ag phase is found to decrease with decrease in Ag loading. The XRD patterns of $\mathrm{Cu}$ rich catalysts $(0.25 \mathrm{Ag}-0.75 \mathrm{Cu} / \mathrm{C}$ and $0 \mathrm{Ag}-1 \mathrm{Cu} / \mathrm{C}$ catalysts) show diffraction lines at a d-value of 2.0871 and at $2 \theta$ value of $43.317^{0}$ due to metallic $\mathrm{Cu}$ (111) plane (ICSD File No. 064699). The broad signal at a d-value of 3.3846 ( $2 \theta$ value of 26.310) is due to the presence of carbon (ICSD File No. 029123). The broad signal at a $2 \theta$ value of $43^{0}$ may be due to the poor crystalline nature of activated carbon. Crystallite sizes of Ag from XRD line Broadening (XLB) by using Debye - Scherrer equation (for the calculation of crystallite sizes, raw XRD data has been used) are shown in Table 1. It is clear that the crystallite size of Ag decreases with decrease in Ag loading. Because of the small intense signal due to $\mathrm{Cu}$ (111) plane, it is difficult to calculate the crystallite size. In $0.5 \mathrm{Ag}-0.5 \mathrm{Cu} / \mathrm{C}$ catalyst, the particle size of $\mathrm{Ag}$ is $38 \mathrm{~nm}$ whereas the particle size of $\mathrm{Cu}$ is below the detection limit of XRD unit.

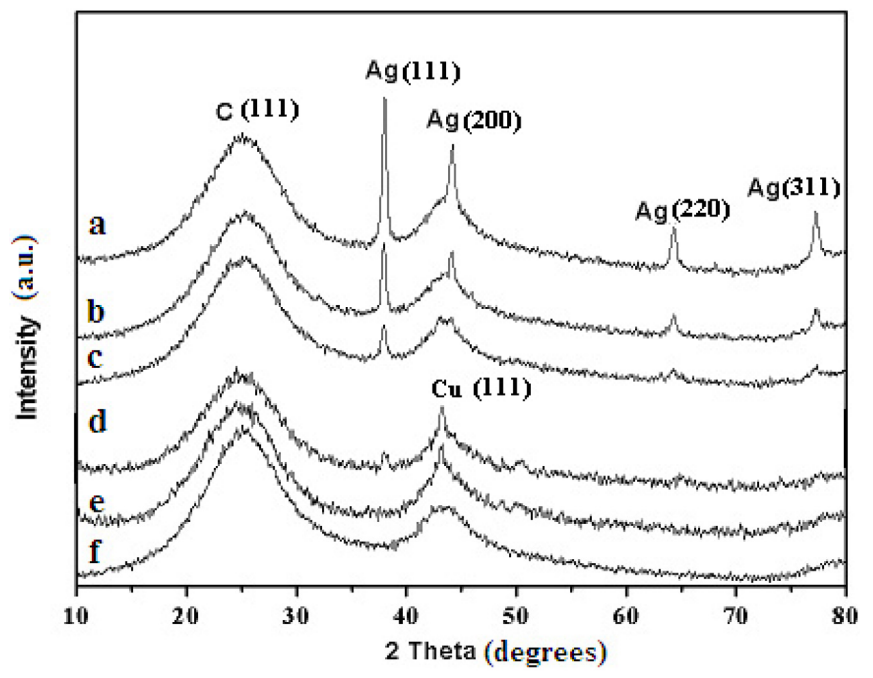

Fig. (1). X-ray powder diffraction patterns of $\mathrm{Ag}-\mathrm{Cu} / \mathrm{C}$ catalysts (a) $1 \mathrm{Ag}-0 \mathrm{Cu} / \mathrm{C} \quad$ (b) $0.75 \mathrm{Ag}-0.25 \mathrm{Cu} / \mathrm{C} \quad$ (c) $0.5 \mathrm{Ag}-0.5 \mathrm{Cu} / \mathrm{C} \quad$ (d) $0.25 \mathrm{Ag}-0.75 \mathrm{Cu} / \mathrm{C}(\mathbf{e}) 0 \mathrm{Ag}-1 \mathrm{Cu} / \mathrm{C}$ (f) Carbon.

Fig. (2) shows the TEM pictures of $1 \mathrm{Ag}-0 \mathrm{Cu} / \mathrm{C}, 0.5 \mathrm{Ag}-$ $0.5 \mathrm{Cu} / \mathrm{C}$ and $0 \mathrm{Ag}-1 \mathrm{Cu} / \mathrm{C}$ catalysts in reduced state. It is interesting to note that the $\mathrm{Ag}$ particle size in $1 \mathrm{Ag}-0 \mathrm{Cu} / \mathrm{C}$ is approximately $50 \mathrm{~nm}$ and in $0.5 \mathrm{Ag}-0.5 \mathrm{Cu} / \mathrm{C}$ catalyst is approximately $10 \mathrm{~nm}$ (Table 2). Particles of $\mathrm{Cu}$ are not visible in the TEM pictures of $0.5 \mathrm{Ag}-0.5 \mathrm{Cu} / \mathrm{C}$ and $0 \mathrm{Ag}-$ $1 \mathrm{Cu} / \mathrm{C}$ catalysts. These results are in line with those obtained from XRD. Formation of nanoparticles of $\mathrm{Ag}$ and $\mathrm{Cu}$ on a high surface area support like activated carbon is not surprising when the concentration of metal content is small. In the present investigation, the total metal content is only $1 \%$ by weight and hence there is possibility of formation of $\mathrm{Ag}$ and $\mathrm{Cu}$ nanoparticles. It is reported the formation of $\mathrm{Cu}$ nano particles on a low surface are support like $\mathrm{MgO}$, when the $\mathrm{Cu}$ metal content is up to $20 \%$ by weight [19-21] It is reported that silver particle size is in the nano range when $\mathrm{Ag}$ is deposited on activated carbon and carbon covered alumina $[22,16]$.

Fig. (3) shows the TPR patterns of the catalysts. TPR is one of most useful characterization technique in the area of catalysis, particularly to find out the presence of reducible 

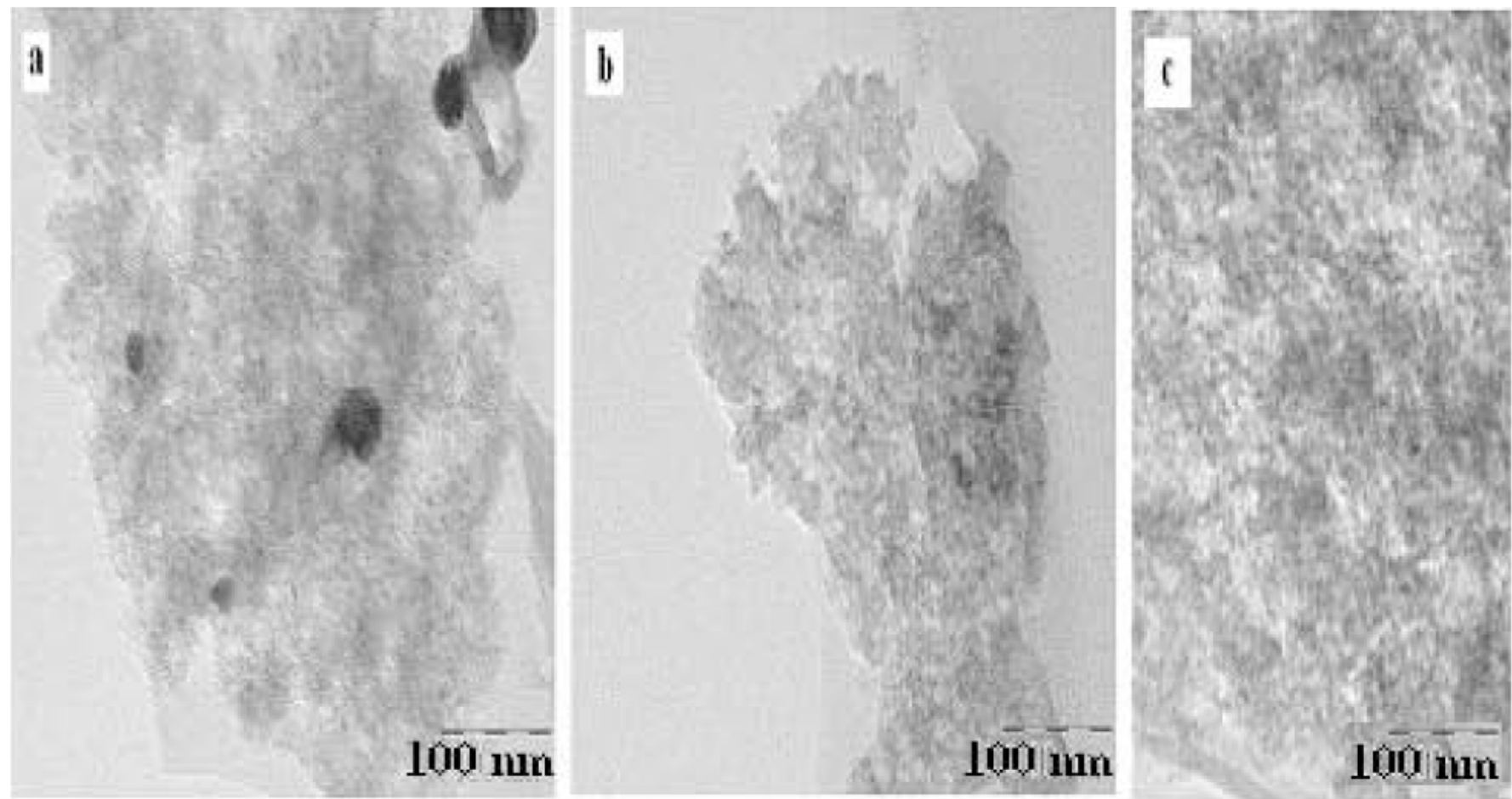

Fig. (2). TEM pictures of $\mathrm{Ag}-\mathrm{Cu} / \mathrm{C}$ catalysts. (a) $1 \mathrm{Ag}-0 \mathrm{Cu} / \mathrm{C}$ (b) $0 \mathrm{Ag}-1 \mathrm{Cu} / \mathrm{C}(\mathbf{c}) 0.5 \mathrm{Ag}-0.5 \mathrm{Cu} / \mathrm{C}$.

Table 2. Surface Concentration and Particle Size of Ag and Cu from XPS and TEM Respectively

\begin{tabular}{|c|c|c|c|c|c|}
\hline \multirow{2}{*}{ S. No. } & \multirow{2}{*}{ Catalyst Code } & \multicolumn{2}{|c|}{ Mass Concentration (XPS), wt \% } & \multicolumn{2}{|c|}{ Particle Size (TEM), nm } \\
\cline { 3 - 6 } & & $\mathbf{A g}$ & $\mathbf{C u}$ & \multicolumn{2}{|c|}{$\mathbf{A g}$} \\
\hline \hline 1 & $1 \mathrm{Ag}-0 \mathrm{Cu} / \mathrm{C}$ & 1.87 & 0 & 10 & - \\
\hline 2 & $0.5 \mathrm{Ag}-0.5 \mathrm{Cu} / \mathrm{C}$ & 1.12 & 2.07 & - & - \\
\hline 3 & $0 \mathrm{Ag}-1 \mathrm{Cu} / \mathrm{C}$ & 0 & 0.44 & - \\
\hline
\end{tabular}

species, oxidation state of active component and the interaction between active component species. The peak significant in all the samples at around a $T_{\max }$ of $920 \mathrm{~K}$ corresponds to gasification of carbon, where methane formation occurs.

$\mathrm{C}+2 \mathrm{H}_{2} \longrightarrow \mathrm{CH}_{4}$

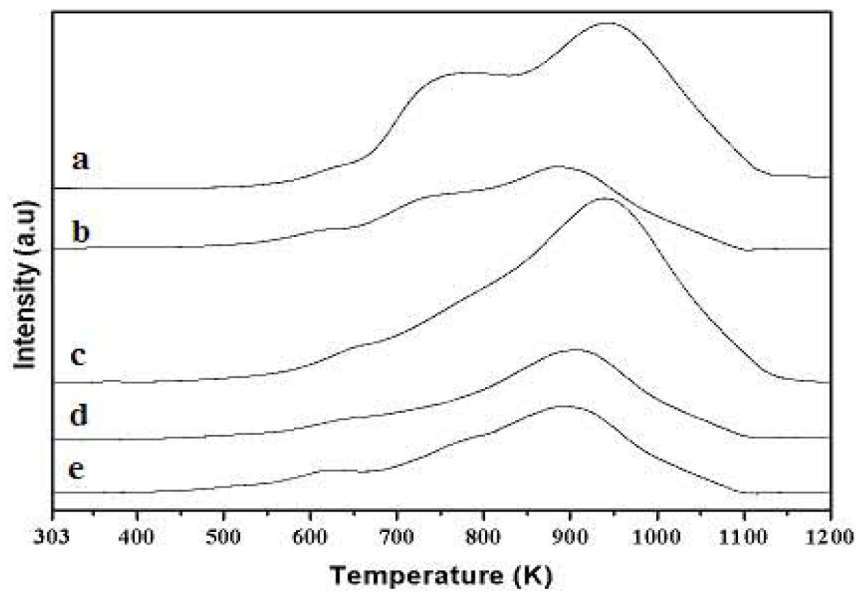

Fig. (3). TPR Patterns of $\mathrm{Ag}-\mathrm{Cu} / \mathrm{C}$ catalysts. (a) $1 \mathrm{Ag}-0 \mathrm{Cu} / \mathrm{C}$ (b) $0.75 \mathrm{Ag}-0.25 \mathrm{Cu} / \mathrm{C} \quad$ (c) $\quad 0.5 \mathrm{Ag}-0.5 \mathrm{Cu} / \mathrm{C} \quad$ (d) $0.25 \mathrm{Ag}-0.75 \mathrm{Cu} / \mathrm{C} \quad(\mathbf{e})$ $0 \mathrm{Ag}-1 \mathrm{Cu} / \mathrm{C}$.
Carbon gasification at high temperatures beyond $750 \mathrm{~K}$ were reported on Ag catalysts in our earlier publications [16, 22]. High temperature signal due to carbon gasification in the TPR patterns of Pd supported on carbon based supports were reported [23-28].

From the TPR pattern of $0 \mathrm{Ag}-1 \mathrm{Cu} / \mathrm{C}$ catalyst $(1 \% \mathrm{Cu})$ one can observe the reduction of carbon at relatively lower temperatures. The reduction of $\mathrm{Cu}^{+1}$ oxide to metallic $\mathrm{Cu}$ can be observed at a $T_{\max }$ of $\sim 600 \mathrm{~K}$ in this catalyst.

$\mathrm{Cu}_{2} \mathrm{O}+\mathrm{H}_{2} \longrightarrow \mathrm{Cu}+\mathrm{H}_{2} \mathrm{O}$

The silver oxide reduction to metallic $\mathrm{Ag}$ can be observed from the TPR patterns of $0.75 \mathrm{Ag}-0.25 \mathrm{Cu} / \mathrm{C} \mathrm{ca}$, $1 \mathrm{Ag}-0 \mathrm{Cu} / \mathrm{C}$ catalysts at a $\mathrm{T}_{\max }$ of $\sim 750 \mathrm{~K}$. From the TPR pattern of $0.50 \mathrm{Ag}-0.5 \mathrm{Cu} / \mathrm{C}$ catalyst, it is interesting to observe a broad single peak due to the reduction of carbon and a shoulder at a $\mathrm{T}_{\max }$ of $650 \mathrm{~K}$ may be due the reduction of strongly interacted species or alloy formation between $\mathrm{Cu}$ and Ag oxides.

$\mathrm{Ag}_{2} \mathrm{O}+\mathrm{H}_{2} \longrightarrow \mathrm{Ag}+\mathrm{H}_{2} \mathrm{O}$

Thus the TPR results indicate the presence of reducible species which are present in the catalyst. In the present case, the reducible species in the catalysts are $\mathrm{Cu}_{2} \mathrm{O}, \mathrm{Ag}_{2} \mathrm{O}$ and carbon. Since metallic silver and other coinage metals are 
active in controlling the microorganism the catalysts in the oxidic form must be reduced to the corresponding metals before their application in water purification.

The XPS patterns of $1 \mathrm{Ag}-0 \mathrm{Cu} / \mathrm{C}, 0.5 \mathrm{Ag}-0.5 \mathrm{Cu} / \mathrm{C}$ and $0 \mathrm{Ag}-1 \mathrm{Cu} / \mathrm{C}$ in reduced state) are shown in Fig. (4). The binding energy values of $\mathrm{Ag} 3 \mathrm{~d}_{5 / 2}$ in $1 \mathrm{Ag}-0 \mathrm{Cu} / \mathrm{C}$ and $0.5 \mathrm{Ag}-$ $0.5 \mathrm{Cu} / \mathrm{C}$ catalysts are 368.298 and $368.178 \mathrm{eV}$ respectively. The binding energy values of $\mathrm{Cu} 3 \mathrm{~d}_{3 / 2}$ in $0 \mathrm{Ag}-1 \mathrm{Cu} / \mathrm{C}$ and $0.5 \mathrm{Ag}-0.5 \mathrm{Cu} / \mathrm{C}$ catalysts are 932.477 and $932.344 \mathrm{eV}$ respectively. The decrease of binding energy values for $\mathrm{Ag}$ $3 \mathrm{~d}_{5 / 2}$ and $\mathrm{Cu} 3 \mathrm{~d}_{3 / 2}$ in $0.5 \mathrm{Ag}-0.5 \mathrm{Cu} / \mathrm{C}$ catalyst compared to those in the monometallic catalysts might be due the interaction beteen $\mathrm{Ag}$ and $\mathrm{Cu}$ phases. Merging of $\mathrm{Cu}$ and $\mathrm{Ag}$ oxide reduction peaks in the TPR pattern of $0.5 \mathrm{Ag}-0.5 \mathrm{Cu}$ catalyst confirms the formation of interacted species between $\mathrm{Ag}$ and $\mathrm{Cu}$.

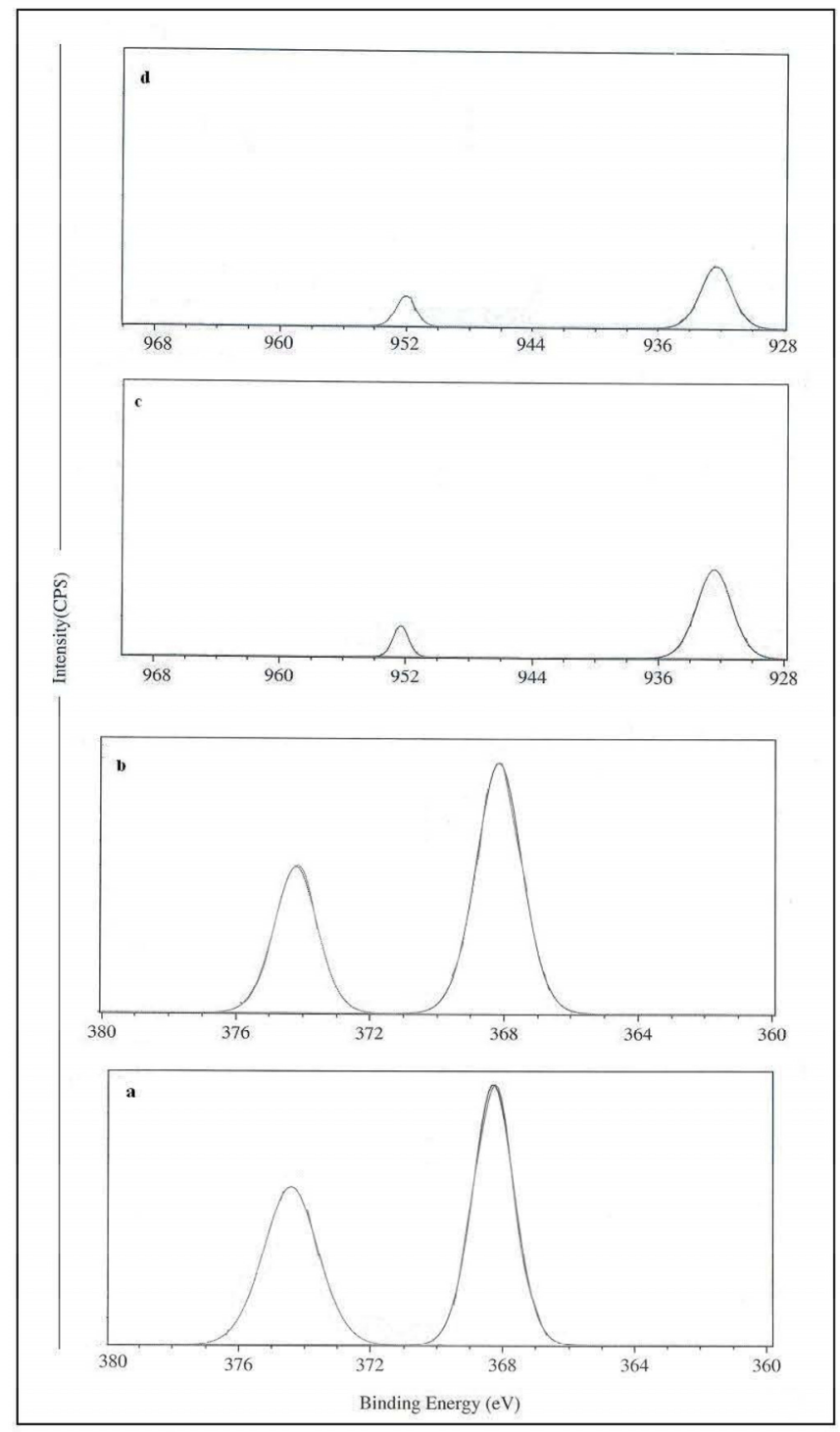

Fig. (4). XPS results of $\mathrm{Ag}-\mathrm{Cu} / \mathrm{C}$ catalysts. (a) $1 \mathrm{Ag}-0 \mathrm{Cu} / \mathrm{C}(\mathrm{Ag}$ $3 \mathrm{~d}_{5 / 2}$ pattern) (b) $0.5 \mathrm{Ag}-0.5 \mathrm{Cu} / \mathrm{C}\left(\mathrm{Ag} 3 \mathrm{~d}_{5 / 2}\right.$ pattern) $(\mathbf{c}) 0 \mathrm{Ag}-1 \mathrm{Cu} / \mathrm{C}$ $\left(\mathrm{Cu} 2 \mathrm{p}_{3 / 2}\right.$ pattern) (d) $0.5 \mathrm{Ag}-0.5 \mathrm{Cu} / \mathrm{C}\left(\mathrm{Cu} 2 \mathrm{p}_{3 / 2}\right.$ pattern).

Table 2 shows the surface composition and particle size of $\mathrm{Ag}$ and /or $\mathrm{Cu}$ in $1 \mathrm{Ag}-0 \mathrm{Cu} / \mathrm{C}, 0.5 \mathrm{Ag}-0.5 \mathrm{Cu} / \mathrm{C}$ and $0 \mathrm{Ag}-$ $1 \mathrm{Cu} / \mathrm{C}$ catalysts (reduced state) from the XPS and TEM data.
The surface composition of $\mathrm{Ag}(1.87 \%)$ in $1 \mathrm{Ag}-0 \mathrm{Cu} / \mathrm{C}$ is more than that of $\mathrm{Cu}(0.44 \%)$ in $0 \mathrm{Ag}-1 \mathrm{Cu} / \mathrm{C}$. However, the surface composition of $\mathrm{Ag}$ (1.12) is lower than that of $\mathrm{Cu}$ (2.07) in $0.5 \mathrm{Ag}-0.5 \mathrm{Cu} / \mathrm{C}$ catalyst. From this one can guess that $0.5 \mathrm{Ag}-0.5 \mathrm{Cu} / \mathrm{C}$ possesses more anti microbial activity than the individual catalysts. Among the individual catalysts, $1 \mathrm{Ag}-0 \mathrm{Cu} / \mathrm{C}$ expects to exhibit more anti microbial activity than that of $0 \mathrm{Ag}-1 \mathrm{Cu} / \mathrm{C}$. However, the smaller particles which are evident from the XRD and particle size from TEM (Table 2) of $\mathrm{Cu}$ in $0 \mathrm{Ag}-1 \mathrm{Cu} / \mathrm{C}$ than that of $\mathrm{Ag}$ in $1 \mathrm{Ag}-0 \mathrm{Cu} / \mathrm{C}$ may be a better catalyst in terms of microorganism control among the individual catalysts.

\section{Catalytic Activity}

A report discusses three mechanisms of deactivation that silver utilizes to incapacitate disease-causing organisms [29]. These are catalytic oxidation, reaction with cell membranes, and binding with DNA of disease organisms to prevent unwinding. Among all the metals, silver is unique in its affinity towards oxygen. It is reported that atomic oxygen has an almost prefect fit in the octahedral holes of gold, silver and copper. However, in gold the electron cloud of oxygen tends to be expelled by lattice oxygen of gold atoms and this blocks the movement through holes. Copper, on the other hand, forms the oxide providing an impossible barrier. Silver offers so little repulsion to oxygen that only a small amount of thermal energy is required to readily move the atomic oxygen through the silver lattice [30]. Micro-crystals of silver have a tendency to lightly bound nascent oxygen (with a binding energy of only $40 \mathrm{kcal} / \mathrm{mol}$ ) and these species readily oxidizes bacteria or viruses, resulting in complete disintegration [31]. Silver in its atomic state, has the capacity to absorb oxygen and act as a catalyst to bring about oxidation. Because oxygen is more electronegative than sulfur, atomic (nascent) oxygen absorbed onto the surface of silver particles in solution will readily react with hydrogen attached to sulfur in the sulfhydryl $(-\mathrm{S}-\mathrm{H})$ groups surrounding the surface of bacteria or viruses. The removal of hydrogen atoms (as water) causes the sulfur atoms to condense to form R- S -S- R bond. This blocks the respiration and causing the bacteria to expire.

$$
\mathrm{R}-\mathrm{S}-\mathrm{H}+\mathrm{O}+\mathrm{H}-\mathrm{S}-\mathrm{R} \stackrel{\mathrm{Ag}-\mathrm{Cu}}{\longrightarrow} \mathrm{R}-\mathrm{S}-\mathrm{S}-\mathrm{R}+\mathrm{H}_{2} \mathrm{O}
$$

\section{Quantification of Microorganisms}

Raw water contains large number of colonies. After $24 \mathrm{~h}$ incubation, the number of colonies in raw water is $125 \times 10^{6}$ CFU. This number goes upto to $178 \times 10^{6} \mathrm{CFU}$ after $48 \mathrm{~h}$ incubation. Fig. (5) compares the microorganism destruction ability of reduced $\mathrm{Ag}-\mathrm{Cu} / \mathrm{C}$ catalysts with various compositions of silver and copper. Both $\mathrm{Ag}$ and $\mathrm{Cu}$ catalysts are known to possess good anti bacterial activity [16, 22, 32, 33]. However in the present investigation, the catalytic activity of $0 \mathrm{Ag}-1 \mathrm{Cu} / \mathrm{C}$ catalyst is more compared to that of $1 \mathrm{Ag}-0 \mathrm{Cu} / \mathrm{C}$ catalyst. This is due to the smaller particle size of $\mathrm{Cu}$ compared to the silver particle size. No $\mathrm{Cu}$ particle is visible in the TEM picture of $0 \mathrm{Ag}-1 \mathrm{Cu} / \mathrm{C}$ catalyst, indicationg that $\mathrm{Cu}$ particle size is very small. On the otherhand, $\mathrm{Ag}$ particle size in $1 \mathrm{Ag}-0 \mathrm{Cu} / \mathrm{C}$ catalyst is in the range of $50 \mathrm{~nm}$. XRD and TEM data supports this evidence. The data of quantitative analysis of microorganisms present in the water samples after treating with $\mathrm{Ag}-\mathrm{Cu}$ catalysts 
clearly indicates the highly efficient nature of $0.5 \mathrm{Ag}$ $0.5 \mathrm{Cu} / \mathrm{C}$ catalyst towards controlling the microorganism. The raw water, i.e., without a catalyst that is tested has shown the presence of large number of bacterial colonies. Even, with activated carbon, the catalytic activity in controlling the microorganism is negligible. The high activity (nearly $80 \%$ ) possessed by $0.5 \mathrm{Ag}-0.5 \mathrm{Cu} / \mathrm{C}$ catalyst is due to (i) the strong interaction between $\mathrm{Ag}$ and $\mathrm{Cu}$, (ii) presence of smaller particles of $\mathrm{Ag}$ and $\mathrm{Cu}$ and (iii) more amount surface composition of $\mathrm{Ag}$ and $\mathrm{Cu}$.

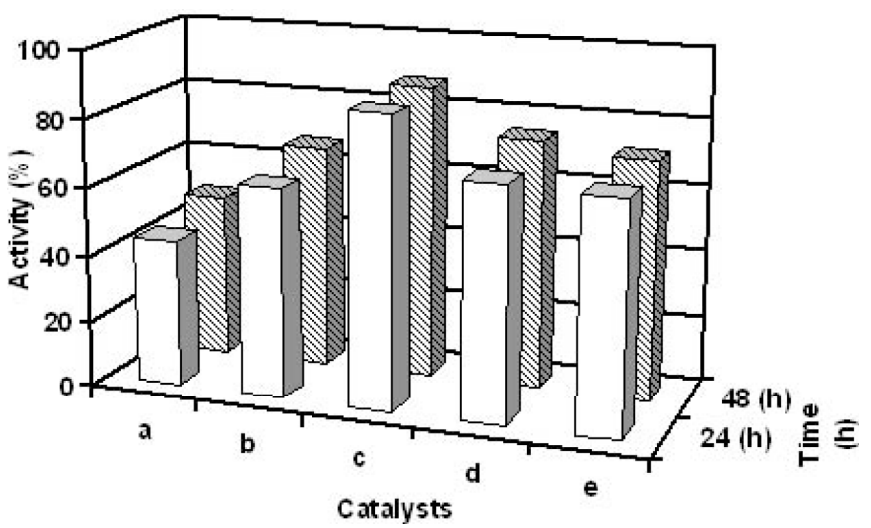

Fig. (5). Activity data of $\mathrm{Ag}-\mathrm{Cu} / \mathrm{C}$ catalysts. (a) $1 \mathrm{Ag}-0 \mathrm{Cu} / \mathrm{C}$ (b) $0.75 \mathrm{Ag}-0.25 \mathrm{Cu} / \mathrm{C} \quad$ (c) $0.5 \mathrm{Ag}-0.5 \mathrm{Cu} / \mathrm{C} \quad$ (d) $0.25 \mathrm{Ag}-0.75 \mathrm{Cu} / \mathrm{C} \quad$ (e) $0 \mathrm{Ag}-1 \mathrm{Cu} / \mathrm{C}$.

\section{CONCLUSIONS}

From the activity it is clear that the best catalyst is the one with equal proportions of silver and copper, (0.5 Ag$0.5 \mathrm{Cu} / \mathrm{C}$ catalyst). This is be due to the strong interacted species between $\mathrm{Ag}$ and $\mathrm{Cu}$ (which can be evidenced from the TPR and XPS data), the presence of smaller particles of $\mathrm{Ag}$ and $\mathrm{Cu}$ as evidenced from the XRD and TEM results and more amount surface composition of $\mathrm{Ag}$ and $\mathrm{Cu}$. As the price of silver is costlier than copper, the diluted catalyst with equal proportions of $\mathrm{Ag}$ and $\mathrm{Cu}$ is much lower cost with higher catalytic activity towards microorganism control in drinking water.

\section{ACKNOWLEDGEMENT}

Authors, Hari Prasad Reddy and Anand acknowledge CSIR, New Delhi, India for the award of research fellowship.

\section{REFERENCES}

[1] Prashant, J.; Pradeep, T. Potential of silver nanoparticle-coated polyurethane form as an antibacterial water filter. Biotechnol. Bioeng., 2005, 90, 59-63.

[2] Yaohui, L.V.; Liu, H.; Wang, Z.; Liu, S.; Hao, L.; Sang, Y.; Liu, D.; Wang, J.; Boughton, R. I. Silver nanoparticle-decorated porous ceramic composite for water treatment. J. Memb. Sci., 2009, 331, 50-56.

[3] Droste, R.L. Theory and Practice of Water and Wastewater Treatment. Wiley, New York, 1997.

[4] James, G.V. Water Treatment, 4th ed., CRC Press, Cleveland, OH, 1971, p. 38.

[5] Tokumaru, T.; Shimizu, Y.; Fox, C.L. Antiviral activities of silver sulfadiazine and ocular infection. Res. Commun. Chem. Pathol. Pharmacol, 1974, 8, 151-158.

[6] Fox, C.L.; Rappole, B.W.; Stanford, W. Control of pseudomonas infection in burns by silver sulfadiazine. Surgery, Gynecol. Obstetrics, 1969, 128, 1021-1026.
Feng, Q.L.; Wu, J.; Chen, G.Q.; Cui, F.Z.; Kim, T.N.; Kim, J.O. A mechanistic study of the antibacterial effect of silver ions on Escherichia coli and Staphylococcus aureus. J. Biomed. Mater. Res., 2000, 52, 662-668.

[8] Zuhuang, J. Bactericidal nano-silver cloth and its making process and use, CN Patent 1387700, 2003.

[9] Chen, M.; Chen, S. Process for preparing antibacterial antimildew polyacrylic fibers and its filter net for air conditioner. CN Patent 1355335, 2002.

[10] Lee, H.J.; Yeo, S.Y.; Jeong, S.H. Antibacterial effect of nanosized silver colloidal solution on textile fabrics. J. Mater. Sci., 2003, 38 , 2199-2204.

[11] Fechner, J.H.; Zimmer, J. Glass-ceramic composite containing nanoparticles. WO Patent 03059834, 2003.

[12] Wang, Q.F.; Yu, H.J.; Zhong, L.; Liu, J.Q.; Sun, J.Q.; Shen, J.C. Incorporation of silver ions into ultrathin titanium phosphate films: in situ reduction to prepare silver nanoparticles and their antibacterial activity. Chem. Mater., 2006, 8, 1988-1994.

[13] Ichinose, N. Superfine Particle Technology, Springer, Berlin, 1992.

[14] Stoimenov, P.K.; Klinger, R.L.; Marchin, G.L.; Klabunde, K. J. Metal oxide nanoparticles as bactericidal agents. Langmuir, 2002, 18, 6679-6686.

[15] Zhang, L.Z.; Yu, J.C.; Yip, H.Y.; Li, Q.; Kwong, K.W.; Xu, A.W.; Wong, P.K. Ambient light reduction strategy to synthesize silver nanoparticles and silver--coated $\mathrm{TiO}_{2}$ with enhanced photocatalytic and bactericidal activities. Langmuir, 2003, 19, 10372-10380.

[16] Shashikala, V.; Siva Kumar, V.; Padmasri, A.H.; David Raju, B. Venkata Mohan, S.; Nageswara Sarma, P.; Rama Rao, K.S. Advantages of nano-silver-carbon covered alumina catalyst prepared by electro-chemical method for drinking water purification. J. Mol. Catal. A, 2007, 268, 95-100.

[17] Padmasri, A.H.; Venugopal, A.; Krishnamurthy, J.; Rama Rao, K.S.; Kanta Rao. P. Novel calcined Mg-Cr hydrotalcite supported $\mathrm{Pd}$ catalysts for the hydrogenolysis of $\mathrm{CCl}_{2} \mathrm{~F}_{2}$. J. Mol. Catal. A 2002, 181, 73-80.

[18] Gschlegel, H. General Microbiology, seventh ed., Cambridge University Press, New York, 1995.

[19] Nagaraja, B.M.; Padmasri, A.H.; David Raju, B.; Rama Rao, K.S. Vapor phase selective hydrogenation of furfural to furfuryl alcohol over $\mathrm{Cu}-\mathrm{MgO}$ coprecipitated catalysts. J. Mol. Catal. A, 2007, 265, 90-95.

[20] Nagaraja, B.M.; Siva Kumar, V.; Shasikala, V.; Padmasri, A.H.; Sreedhar, B.; David Raju, B.; Rama Rao, K.S. A highly efficient $\mathrm{Cu} / \mathrm{MgO}$ catalyst for vapour phase hydrogenation of furfural to furfuryl alcohol. Catal. Commun., 2003, 4, 287-293.

[21] Nagaraja, B.M.; Siva Kumar, V.; Shasikala, V.; Padmasri, A.H.; Sreevardhan Reddy, S.; David Raju, B.; Rama Rao, K.S. Effect of method of preparation of copper - magnesium oxide catalyst on the dehydrogenation of cyclohexanol. J. Mol.Catal. A, 2004, 223, 339345 .

[22] Siva Kumar, V.; Nagaraja, B.M.; Shashikala, V.; Padmasri, A.H.; Shakuntala Madhavendra, S.; David Raju. B.; Rama Rao, K.S. Highly efficient $\mathrm{Ag} / \mathrm{C}$ catalyst prepared by electro-chemical deposition method in controlling microorganisms in water. $\mathrm{J}$. Mol. Catal. A, 2004, 223, 313-319.

[23] Chandra Shekar, S,; Krishna Murthy, J.; Kanta Rao, P. ; Rama Rao, K.S. Selective hydrogenolysis of dichlorodifluoromethane on carbon covered alumina supported palladium catalyst. J. Mol. Catal. A, 2003, 191, 45-59.

[24] Chandra Shekar, S.; Krishna Murthy, J.; Kanta Rao, P.; Rama Rao, K.S.; Kemnitz, E. Selective hydrogenolysis of dichlorodifluoromethane $\left(\mathrm{CCl}_{2} \mathrm{~F}_{2}\right)$ over CCA supported palladium bimetallic catalysts. J. Appl. Catal. A, 2003, 244, 39-48.

[25] Krishna Murthy, J.; Chandra Shekar, S.; Padmasri, A.H.; Venugopal, A.; Siva Kumar, V.; Nagaraja, B.M.; Shashikala, V.; David Raju, B.; Kanta Rao, P.; Rama Rao, K.S. Promotional effect of magnesia addition to active carbon supported Pd catalyst on the characteristics and hydrodechlorination activity of $\mathrm{CCl}_{2} \mathrm{~F}_{2}$. Catal. Commun., 2004, 5, 161-167.

[26] Krishna Murthy, J.; Chandra Shekar, S.; Siva Kumar, V.; Rama Rao, K.S. Highly selective zirconium oxychloride modified Pd/C catalyst in the hydrodechlorination of dichlorodifluoromethane to difluoromethane. Catal. Commun., 2002, 3, 145 -149.

[27] Krishna Murthy, J.; Chandra Shekar, S.; Siva Kumar, V.; David Raju, B.; Sreedhara B.; Sai Prasad, P.S. ; Kanta Rao, P.; Rama Rao, K.S.; Berry, F.J.; Smart, L.E. Effect of tungsten addition to 
$\mathrm{Pd} / \mathrm{ZrO}_{2}$ system in the hydrodechlorination activity of $\mathrm{CCl}_{2} \mathrm{~F}_{2}$. J. Mol. Catal. A, 2004, 244, 347-357.

[28] Chandra Shekar, S.; Krishna Murthy, J.; Kanta Rao, P.; Rama Rao, K. S. Pd supported on fluorinated carbon covered alumina (FCCA) a high performance catalyst in the hydrodechlorination of dichlorodifluoromethane. Catal Commun., 2003, 4, 39-44.

[29] Davies, R.L.; Etris, S.F. The development and functions of silver in water purification and disease control. Catal. Today, 1997, 36, 107114.

[30] Eberhart, M.E.; Donovan, M.J.; Outlaw, R.A. Ab initio investigations of oxygen diffusion in group IB transition metals. Phys. Rev. B, 1992, 46, 12744-12747.
[31] Heinig, Jr. Composition for bactericidal treatment of water. US Patent. 4608247, 1986

[32] Rama Rao, K. S.; David Raju, B.; Padmasree, A. H.; Siva Kumar, V.; Ratna Kumar, A. N.; Shashikala, V.; Nagaraja, B. M.; Seetha Ramulu, P.; Sreevardhan Reddy, S.; Nageswara Sarma, P.; Krishna Prasad, K.; Venkata Mohan, S. R. Process for preparing silver deposited carbon covered alumina catalyst. US Patent 7662741, 2010.

[33] Ruparelia, J. P.; Chatterjee, A. K.; Duttagupta, S. P.; Duttagupta, S.; Strain specificity in antimicrobial activity of silver and copper nanoparticles. Acta Biomaterialia., 2008, 4, 707-716.

(C) Reddy et al.; Licensee Bentham Open.

This is an open access article licensed under the terms of the Creative Commons Attribution Non-Commercial License (http://creativecommons.org/licenses/by-nc/ $3.0 /$ ) which permits unrestricted, non-commercial use, distribution and reproduction in any medium, provided the work is properly cited. 